\title{
Antiparasitic activity of papaya seed extract (Carica papaya) in free-range local breed chicken (Gallus gallus) production system in Ketou District.
}

Hervé B. Dakpogan $^{a^{*}}$, Venant P. Houndonougbo ${ }^{\mathrm{b}}$, Juste Sègbédji ${ }^{\mathrm{a}}$, Guy A. Mensah ${ }^{\mathrm{c}}$, Saïdou Salifou $^{\mathrm{d}}$

aSchool of Animal Production System Management, P.O.BOX 43 Ketou, National Agricultural University, 01 P.O.BOX 55 Porto-Novo, Benin.

b School of Animal Production Sciences and Techniques, Faculty of Agronomic Sciences 01 P.O.BOX 526, University of Abomey-Calavi, Benin.

'National Agricultural Research Institute of Benin (INRAB), 01 P.O. BOX 884, Cotonou, Benin.

${ }^{\prime}$ National Veterinary Parasitology Laboratory, Polytechnic School of Abomey-Calavi P.O.BOX 2009, University of Abomeycalavi, Benin.

*Corresponding Author: H. B. Dakpogan, School of Animal Production System Management, P.O.BOX 43 Ketou, National Agricultural University, 01 P.O.BOX 55 Porto-Novo, Benin.Tel: 00229946258 36. E-mail: dakpogan2002@yahoo.fr.

Keywords: Carica papaya, Ascaridia galli, Eimeria sp, Heterakis sp, Capillaria sp.

Publication date 31/08/2019, http://www.m.elewa.org/JAPS

\section{SUMMARY}

A field study with a completely randomized design was carried out to evaluate the antiparasitic activity of dried seed meal of unripe mature papaya fruit on gastrointestinal parasites of the traditional chicken farming system in Ketou district. The targeted parasites were Ascaridia galli, Eimeria sp., Capillaria sp. and Heterakis sp. Nine chicken flock units of at least 10 local chicken were enrolled in the study which makes three experimental groups of chickens with three replications per treatment. The first group was treated with the Niclosamide-levamisole molecule complex, a conventional chicken antiparasitic drug (VPV: Vermifuge Polyvalent Volaille) with one tablet orally given to an individual adult and half a tablet orally given to an individual young chicken. The second group received, in drinking water, dried seed meal of papaya fruit at a dosage of $1 \mathrm{mg}$ per chicken for 5 days. The third group received drinking water as a placebo. A total of 198 faecal samples were analysed in the laboratory with the quantitative flotation method using the McMaster Chamber. The results obtained demonstrated the effectiveness of Carica papaya extract treatment on coccidia in the first place and also on Ascaridia galli with effects comparable to that of the conventional antiparasitic drugs used in commercial chicken production system. The efficiency time period was 3 weeks for the extract of Carica papaya. This means that the treatment must be renewed every 3 weeks to guarantee its effectiveness. However, the most appropriate dose remains to be elucidated and the use of other organs of the plant for better efficacy will be the subjects of further investigations. 


\section{INTRODUCTION}

Chicken is an important protein source because of its short production cycle (Smil, 2002). The local chicken plays an important socio-cultural role in rural community; frequently used for traditional pharmacopoeia, various festive occasions, wedding ceremonies, gift, and meal for important guests (Guèye et al., 1998, Fotsa et al., 2007). The paramount role of traditional poultry farming in Benin both in rural household economy and in global national meat supply (second source of meat after beef) makes of this activity a potential strategic tool for rural poverty alleviation (Sodjinou, 2011). Unfortunately, traditional poultry farming development is hampered by devastating pathologies (Dakpogan et al., 2011) even though it is going through a transitional period in the developing countries, going from a simple activity of subsistence to a more commercial activity. If we agree to incriminate infectious diseases whose control is not for tomorrow in scavenging poultry systems, we must not lose sight of the parasitic diseases that remain, for the most part, insidious in holdings with the effect of lower performance. These diseases, although not often direct causes of mortality in chickens, cause considerable economic losses due, on the one hand, to the decrease in bird resistance to other diseases, and on the other hand, cause reduction in production and

\section{MATERIALS AND METHODS}

3.1 Study design and experimental groups : The study is a two-month longitudinal field study carried out in a completely randomized design, in Ketou district, an Eastsouthern region of Benin ( $7^{\circ} 10^{\prime}$ and $7^{\circ} 41^{\prime} 17$ " $\mathrm{N} 2^{\circ} 24^{\prime} 24^{\prime \prime}$ and $2^{\circ} 47^{\prime} 40^{\prime \prime} \mathrm{E}, 1775 \mathrm{~km}^{2}, 1.55 \%$ of the national territory). The objective was to evaluate the antiparasitic activity of sun-dried seed meal of unripe mature papaya fruit (Carica papaya) on chicken gastrointestinal parasites such as Eimeria sp. Ascaridia galli, Heterakis sp. and Capillaria sp. frequently encountered in smallholder free-range poultry production system (Permin and Hansen, 1998). Nine (9) productivity. For the farmers, it is therefore essential to find less costly and accessible means of controlling those affections. The use of medicinal plants dates back several centuries and is one of the best profits that man derives from plant resources. At present, treatments based on medicinal plants are little valued because studies to confirm their effectiveness following a scientific approach and analysis remain few (Kasonia and Ansey, 1993). However, in the semi-intensive exotic chicken breed production system, some medicinal plants like Andrographis paniculata, Sophora flavescens, Allium sativum, Salvia officinalis, Echinacea purpurea, Thymus vulgaris, Origanum vulgare, Artemisia sp., Foeniculum vulgare have been substantially investigated with promising reports (Youn and Noh, 2001; Sujikara, 2000; Arczewska and Swiatkiewicz, 2010; Shazia et al., 2013; Emilio et al., 2013; Loredana et al., 2015). Dakpogan et al. (2018) reported the anticoccidial effect of papaya leaf extract on exotic chicks experimentally infected with Eimeria tenella. The current study came up with the effect of dried seed meal of unripe mature Carica papaya fruit on Eimeria sp., Ascaridia galli, Heterkis sp. and Capillaria sp. in free-range local chicken production system in Ketou district, Benin.

smallholder free-range chicken flocks of local breeds with a minimum size of 10 chickens were enrolled in the study and randomly allocated into three experimental groups of three (3) flocks each (three replications). The first group was treated with conventional antiparasitic drug a complex Niclosamidelevamisole (VPV: Vermifuge Polyvalent Volaille). One tablet was orally given to an individual adult and half a tablet orally given to an individual young chicken. The second group received the dried seed meal of papaya fruit in drinking water for 5 days with a dose of $1 \mathrm{mg}$ per chicken. The third group was the control 
group where the chickens received simple drinking water for 5 days. The treatment was repeated once with 4 weeks between the two treatments.

3.2 Data Collection: Fresh faecal samples were collected in the morning across each chicken flock unit during the 4 weeks following the starting of the treatment. Five samples were collected during 5 five successive days in the first week following the starting of the treatment and 2 samples on day one and two in the remaining 3 weeks. A total of 198 faecal samples were collected and coccidian oocysts and nematode eggs were detected and counted in the Laboratory of Research in Animal Ecology and Zoogeography of the National Agriculture University through the quantitative simple flotation method using McMaster chamber (Soulsby, 1986). The targeted parasites were Eimeria sp. Ascaridia galli, Heterakis sp. and Capillaria sp. Eggs and oocysts were identified

\section{$4 \quad$ RESULTS}

Compared to the untreated control flocks infestation rate, Carica papaya extract treatment reduced significantly the Ascaridia galli and Capillaria sp. cumulative infestation rates in treated flocks $(\mathrm{p}<0.05)$, results comparable to using the morphological references developed by Soulsby (1982).

3.3 Statistical analysis: The collected data was stored in Excel 2010 version of Microsoft Corporation and statistical analyses and graphs performed in SPSS software. Cumulative infestation rates of coccidia, Ascaridia, Heterakis and Capillaria were calculated using the frequency procedure and comparisons with the Chisquare test using Logrank's two-by-two comparison method. The efficacy of the treatment over time was evaluated by monitoring the variation of the parasite infestation, in the post-treatment time using the Kaplan Meier survival analysis procedure with Kaplan Meier curves. Means and standard errors of oocysts or eggs per gram of faeces were calculated and compared with the One Way ANOVA procedure and Student $t$ test.

the conventional antiparasitic drug treatment effectiveness. Also, Carica papaya dried seed meal treatment exclusively reduced significantly the Eimeria sp. infestation. Indeed, Heterakis sp. was not so ever affected by the treatments.

Table 1: Cumulative infestation rates

\begin{tabular}{l|c|c|c|c}
\hline Experimental groups & $\begin{array}{c}\text { Ascaridia } \\
\text { galli (\%) }\end{array}$ & $\begin{array}{c}\text { Eimeria } \boldsymbol{s p} . \\
\mathbf{( \% )}\end{array}$ & $\begin{array}{c}\text { Heterakis } \boldsymbol{s} \boldsymbol{p} . \\
\mathbf{( \% )}\end{array}$ & $\begin{array}{c}\text { Capillaria } \boldsymbol{s} \boldsymbol{p} \text {. } \\
\mathbf{( \% )}\end{array}$ \\
\hline \hline Papaya extract & $19.70^{\mathrm{a}}$ & $27.30^{\mathrm{a}}$ & $22.70^{\mathrm{a}}$ & $16.70^{\mathrm{a}}$ \\
Niclosamide-levamisole & $9.10^{\mathrm{a}}$ & $77.30^{\mathrm{b}}$ & $15.20^{\mathrm{a}}$ & $10.60^{\mathrm{a}}$ \\
Control & $39.10^{\mathrm{b}}$ & $73.80^{\mathrm{b}}$ & $13.60^{\mathrm{a}}$ & $31.80^{\mathrm{b}}$ \\
\hline
\end{tabular}

(Values in columns that do not share the same superscript letters are significantly different at the significance level of 0.05).

The number of oocysts or eggs per gram of faeces varied very little among the different experimental groups. The intensity of Ascaridia infestation was reduced by half $(\mathrm{p}<0.05)$ in chicken flock units treated with dried papaya seed meal compared to the untreated control group. 
Table 2: Infestation intensity in positive chicken flocks

\begin{tabular}{l|c|c|c|c}
\hline Experimental Groups & $\begin{array}{c}\text { Ascaridia galli } \\
\mathbf{( \% )}\end{array}$ & $\begin{array}{c}\text { Eimeria sp. } \\
\mathbf{( \% )}\end{array}$ & $\begin{array}{c}\text { Heterakis sp. } \\
\mathbf{( \% )}\end{array}$ & $\begin{array}{c}\text { Capillaria } \\
\text { sp. (\%) }\end{array}$ \\
\hline \hline Papaya extract & $493^{\mathrm{a}} \pm 115$ & $315^{\mathrm{a}} \pm 55$ & $505^{\mathrm{a}} \pm 65$ & $348^{\mathrm{a}} \pm 73$ \\
Niclosamide-levamisole & $806^{\mathrm{ab}} \pm 329$ & $323^{\mathrm{a}} \pm 29$ & $290^{\mathrm{b}} \pm 62$ & $330^{\mathrm{a}} \pm 116$ \\
Control & $1296^{\mathrm{b}} \pm 173$ & $341^{\mathrm{a}} \pm 37$ & $407^{\mathrm{b}} \pm 93$ & $343^{\mathrm{a}} \pm 65$ \\
\hline
\end{tabular}

(Values in columns that do not share the same superscript letters are significantly different at the significance level of 0.05).

Figure 1 shows the efficiency over time of dried papaya seed meal and the conventional deworming agent (Niclosamide-levamisol) treatment on Ascaridia galli, Eimeria sp., Heterakis $s p$ and Capillaria sp. The efficacy of the conventional antiparasitic drug on Ascaridia galli and Capillaria sp. lasted the whole post- treatment experimental period. In contrast, Carica papaya extract treatment was effective on Ascaridia galli and Eimeria sp. infestation for 3 weeks post-treatment period. Neither the conventional deworming nor the meal of the Carica papaya dried seeds affected the flock Heterakis sp. infestation level.

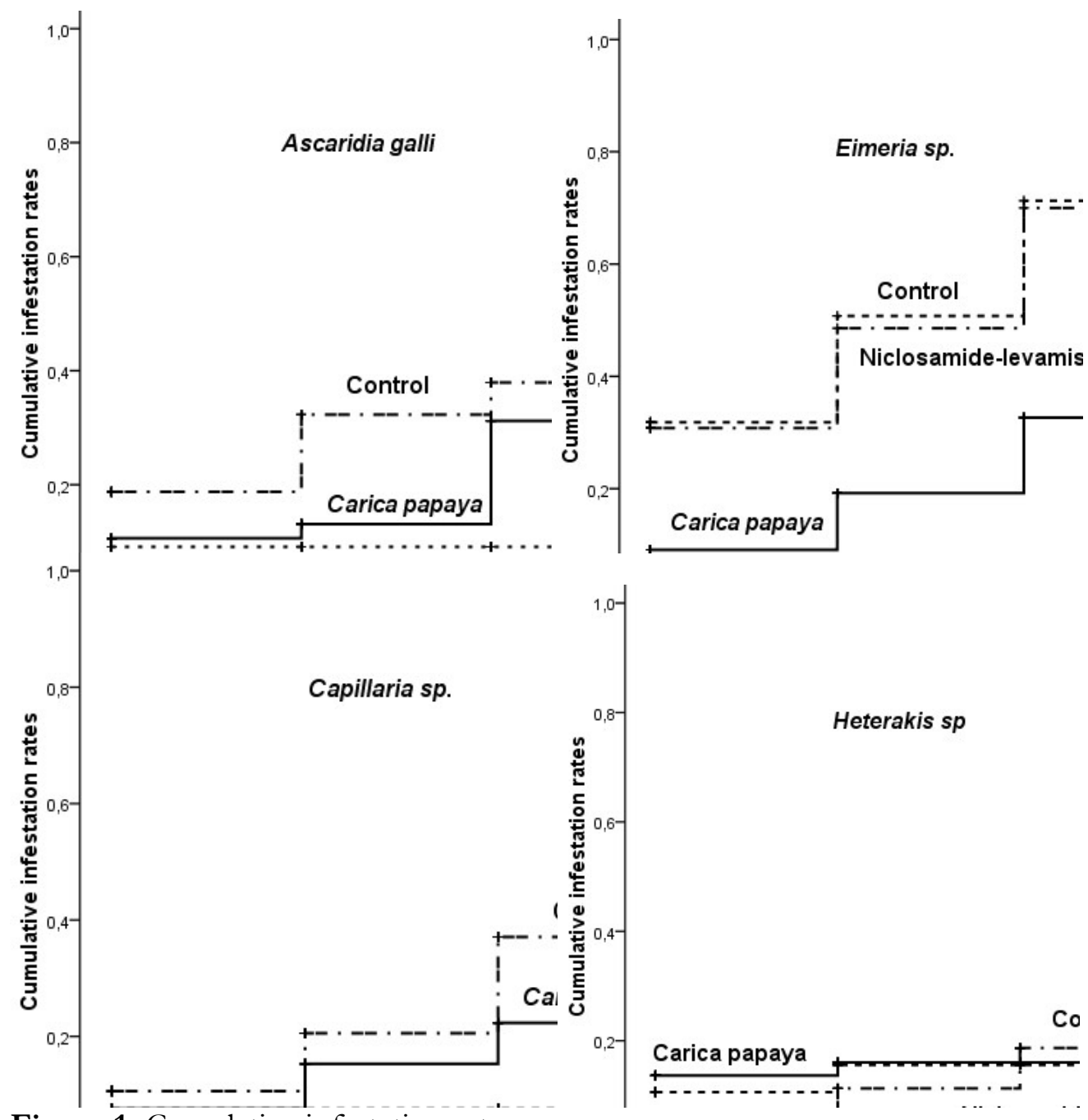

Figure 1: Cumulative infestation rates 
5

The cumulative coccidial infestation rates were $74 \%$ and $27 \%$ for untreated and Carica papaya extract treated chicken flock units respectively. The meal of dried seeds of unripe Carica papaya fruit significantly reduced coccidial infection in chicken flocks that received this meal in drinking water with a reduction rate of $64 \%$ compared to the control untreated group. The low coccidial infestation rate $(27 \%)$ observed in chicken flocks treated with Carica papaya extract during this study is similar to the prevalence of the disease recorded in semi-intensive litterbased exotic layer rearing system with the use in preventive mode of anticoccidians. This prevalence is $27 \%$ (Yunus et al., 2008, Lunden et al., 2010) and 36\% according to Dakpogan and Salifou, (2013a). The Carica papaya fruit seed extract is thus effective in the same way as the conventional anticoccidial drugs used by poultry producers in small-scale commercial poultry production system. The effectiveness of Carica papaya extract on Ascaridia galli and Capillaria sp. infestation in the treated chicken flocks is more moderate, but statistically similar to that induced by the conventional antiparasitic drug the Niclosamide-levamisole complex. The cumulative infestation rates of Ascaridia galli and Capillaria sp were $9 \%$ and $11 \%$, respectively, for the Niclosamidelevamisole complex and $17 \%$ and $19 \%$ for the dried papaya seed extract treatment. The findings are consistent with the results obtained by several authors using various parts of Carica papaya plant. The anthelmintic effect of the latex, leaves and seeds with elimination of human and animal intestinal worms was observed (Okenyi et al., 2007, Sacramento et al., 2010, Arvind et al., 2013). The antiprotozoal effect of the seed extract was demonstrated by Ekanem et al. (2004) on fish parasite organism, Ichthyophthirius multifiliis. Dakpogan et al. (2018) observed the anticoccidial effect of papaya leaf extract on chicken coccidiosis caused by Eimeria tenella. The anthelmintic activity of papaya seeds can be attributed to carpaine, carpasemine (Kermanchai et al., 2001) and proteolytic enzymes such as cysteine proteinase (Stepek et al., 2005) and papain (Arvind et al., 2013) from the fruit. Also, Carica papaya is known for its anti-inflammatory properties, certainly due to its vitamin A content, used against tumors, ulcers and can accelerate wounds healing (Beuth et al., 2001). Dried papaya fruit seed meal and the conventional parasitic drug have no effect on Heterakis sp. The number of eggs per gram of faeces of parasites such as Heterakis sp., Capillaria sp. and the number of oocysts per gram of faeces of Eimeria sp. were not fundamentally affected by the herein applied treatments. However, Carica papaya extract significantly reduced the number of eggs per gram of faeces in Ascaridia galli. The Kaplan Meier curves obtained in this study made it possible to analyse the effectiveness of treatments over time. The experimental chicken flock parasite infestation level reduction effect induced by Carica papaya extract treatment on Ascaridia galli and Eimeria sp lasted almost 3 weeks. After the third week, the proportion of faecal samples positive for Ascaridia galli increased from 10 to $30 \%$, a drastic increase of about $20 \%$, and the proportion of samples positive for Eimeria sp increased from 30 to $55 \%$, an increase of $25 \%$. On the other hand, the effect of the conventional antiparasitic drug on Ascaridia galli and Capillaria sp. last more than four weeks and was constant throughout the experiment time period and beyond. The results of the herein experimental field study highlighted the effectiveness of dried seed meal of Carica papaya unripe mature fruit (green fruit) on Eimeria sp. and Ascaridia galli in traditional smallholder free-range local chicken production system. Difficulties related to producer's access to veterinary conventional drugs, the high cost of anticoccidial products (Dakpogan et al., 2013b) on the one hand, and the problems related to the respect of drug exact posology and the presence of drug residues in poultry products on the other hand make the use of Carica papaya extract a great alternative to control parasitic diseases in family poultry 
production system. The remedy is natural, accessible, easy to use and less costly. However, the most appropriate dose remains to be

\section{REFERENCES}

Arczewska-Wlosek A. and Swiatkiewicz S: 2010. Response of Chickens Infected With Coccidiosis to Herbal Extracts Mix Fed Singly or In Combination with Additives. XIIIth European Poultry Conference, p. 45-50.

Arvind G, Bhowmik D, Duraivel S. and Harish G: 2010. Traditional and medicinal uses of Carica papaya. J. Med. Car. Pap, 1(1): 2320-3862.

Beuth J, Ost BA, Rethfeldt E, Bock PR, Hanish J. and Schneider B: 2001. Impact of complementary oral enzyme application on the postoperative treatment results of breast cancer patients. Results of an epidemiological multicentre retrospective cohort study. Cancer Chemotherapy and Pharmacology, 47: 45-54.

Dakpogan HB, Kyvsgaard NC, Chrysostome CA. and Permin A: 2011. Chick survivability in free-range production system. Family Poultry Communication, 20(1): 4-8.

Dakpogan HB. and Salifou S: 2013. Coccidiose prevalence and intensity in litter based high stocking density layer rearing system of Benin. Journal of Animal and plant sciences, 17(2): 2522-2526.

Dakpogan HB, Salifou S, Gbangbotche A, Houndonougbo F. and Youssao I: 2013. Mode of anticoccidial drug utilization and their financial cost in Benin litter-based exotic layer rearing system. Journal of Parasitology and Vector Biology, 5(3): 27-30.

Dakpogan HB, Mensah S, Attindehou S, Chrysostome C, Aboh A, Naciri M, Salifou S. and Mensah GA: 2018. Anticocidal activity of Carica papaya and Vernonia amygdalina extract. Inter. J. of Biol. Chem. sci., 12 (5): 2101-2108. elucidated and the use of other organs of the plant for better efficacy need to be further investigated.

Ekanem AP, Obiekezie A, Kloas W. and Knopf K: 2004. Effects of crude extracts of Mucuna pruriens (Fabaceae) and Carica papaya (Caricaceae) against the protozoan fish parasite Ichthyophthirius multifiliis. Parasitology Research, 92(5): 361-6.

Emilio DC, Margarita G, María F, Joaquín Q. and Caridad SA: 2010. Effect of artemisinin on oocyst wall formation and sporulation during Eimeria tenella infection. Parasitology International Journal, 59(4): 506-511.

Fotsa JC, Rognon X, Tixierboichard M, Ngou Ngoupayou JD, Pone Kamdem D, Manjeli Y. and Bordas A : 2007. Exploitation de la poule locale (Gallus gallus) en zone de forêt humide du Cameroun. Bulletin de Santé et de Production Animales en Afrique, 55: 59-73.

Gueye EF: 1998. Village egg and fowl meat production in Africa. World's poultry Science Journal, 54: 73-86.

Kasonia K. and Ansey M: 1993. Métissage en santé aniamle de Madagascar à Haiti. Actes du séminaire d'Ethnopharmacopée vétérinaire, Ouagadougou, Burkina Faso, 1993, Edition Botanique Presse Universitaire de Namur-Belgique, CTA, ACCT, P. 21- 28.

Kermanshai R, McCarry B, Rosenfield J, Summary PS, Werethllny EA. and Sorger GJ: 2001. Benzyl isothyocynate in the chief or sole anthelmintic in Papaya seed extract .Phytochem., 5: 427-435.

Loredana P, Adriana G, Alexandru F, Tǎbăranb $\mathrm{M}$, Oana $\mathrm{D}$, Zsuzsa $\mathrm{K}$. and Cristian M: $2015 . \quad$ Effects of artemisinin in broiler chickens 
challenged with Eimeria acervulina, E. maxima and E. tenella in battery trials. Veterinary Parasitology, 214 (3): 264 271.

Lunden A, Thebo P, Gunnarson S, Hooshmand-Rad P, Tauson R. and Uggla A: 2010. Eimeria infections in litter-based, high stocking density systems for loose-housed laying hens in Sweden. British Poultry Science, 41 (4): 440-447.

Okeniyi JA, Ogunlesi TA, Oyelami OA. and Adeyemi LA : 2007. Effectiveness of dried Carica papaya seeds against human intestinal parasitosis a pilot study. J. Med. Food, 10(1): 194-196.

Permin A, Jorgen W. and Hansen: 1998. Epidemiology, diagnosis and control of poultry parasites. Food and Agriculture Organization of the United Nations Rome, Pp 17.

Sacramento TI, Mensah GA. and Adote HS: 2010. Effet antiparasitaire des graines de papaye (Carica papaya) chez l'aulacode (Thryonomys swinderianus Temminck, 1827) d'élevage: cas des aulacodicultures du Sud-Bénin. Int. J. Biol. Chem. Sci., 6(4): 2280-2293.

Shazia A: 2013. Evaluation of anticoccidial activity of aqueous extract of Fomes fomentarius. New York Science Journal pp 6(8).

Smil V: 2002. Worldwide transformation of diets, burdens of meat production and opportunities for novel food proteins. Enzyme Microb. Tech., 30: 305-311.

Sodjinou E: 2011. Poultry-Based Intervention as Tool for Poverty Reduction and Gender Empowerment: Empirical Evidence from Benin. PhD Thesis. Institute of Food and Resource Economics. Faculty of Life Science. University of Copenhagen.239 p. In.

Soulsby EJL: 1982. Helminths, Arthropods and Protozoa of Domesticated Animals, 7th Ed., Lea and Febiger, Philadelphia, 809 p.
Soulsby EJL: 1986. Helminths, Arthropods and Protozoa of domestic Animals. $7^{\text {th }}$ Edn., Beiliere Tindal II, London, pp: 231.

Stepek G, Buttle DJ, Duce IR, Lowe A. and Behnke JM: 2005. Assessment of the anthelmintic effect of natural plant cysteine proteinases against the gastrointestinal nematode, Heligmosomoides polygyrus, in vitro. Parasitology, 130(2): 203-211.

Sujikara 1: 2000. AndrographispaniculataA paper presented at an International Conference on Tropical Agriculture for better health and environment at Kasetsart, University, Kampaengsaen, Nakornpathom, Thailand, p. 7.

Youn HJ. and Noh JW: 2001. Screening of the anticoccidial effect of herb extracts against Eimeria tenella. Vet. Parasitol. 96: 257-263.

Yunus AW, Nasir MK, Farooq U. and Böhm J: 2008. Prevalence of poultry diseases and their interaction with mycotoxicosis in district chakwal: effects of age and flock size. Journal of Animal and Plant Sciences, 18(4): 107-113. 